\title{
Pengaruh Komunikasi Internal dan Gaya Kepemimpinan terhadap Motivasi Kerja ASN
}

\author{
Ari Cahyo Nugroho ${ }^{1}$, and Gunawan Wiradharma ${ }^{2}$ \\ ${ }^{1}$ BPSDMP Jakarta, Kementerian Komunikasi dan Informatika RI \\ ${ }^{2}$ Program Studi Ilmu Komunikasi FHISIP Universitas Terbuka, Indonesia \\ e-mail: aricahyonugroho@gmail.com
}

\begin{tabular}{|c|c|}
\hline Article Info & Abstract \\
\hline $\begin{array}{l}\text { Article history: } \\
\text { Received } \\
\text { Apr } 12^{\text {th }}, 2021 \\
\text { Revised } \\
\text { July } 19^{\text {th }}, 2021 \\
\text { Accepted } \\
\text { July } 26^{\text {th }}, 2021 \\
\text { Published } \\
\text { July } 30^{\text {th }}, 2021\end{array}$ & $\begin{array}{l}\text { Internal conditions and leadership style seem to affect the work motivation of em- } \\
\text { ployees of ASN Human Resources Development Agency of the Ministry of Commu- } \\
\text { nication and Informatics, this is seen from several changes of head of the agency at } \\
\text { the Human Resources Development Agency. The problem formulation for this study } \\
\text { is: How much influence internal communication has on work motivation; How } \\
\text { much influence leadership style has on work motivation; and How much influence } \\
\text { internal communication and leadership style has on work motivation. The results } \\
\text { showed that internal communication and leadership style influenced work motiva- } \\
\text { tion. The correlation coefficient value is } 0.727 \text {, indicating a strong relationship of } \\
\text { the two category research variables. The coefficient of determination value indicates } \\
52.8 \% \text {, interpreted as internal communication and leadership style has an influence } \\
\text { on work motivation and the other } 47.2 \% \text { is influenced by other factors outside of } \\
\text { internal communication and leadership style. Internal communication has a posi- } \\
\text { tive effect, the communication created between leaders and employees has been very } \\
\text { good. Leadership style affects work motivation, leadership style shows open attitude. } \\
\text { Internal communication and leadership style affect work motivation. }\end{array}$ \\
\hline
\end{tabular}

Keywords: internal communication; leadership style; work motivation

\begin{abstract}
Abstrak
Kondisi internal dan gaya kepemimpinan tampak mempengaruhi motivasi kerja karyawan ASN Badan Litbang SDM Kementerian Komunikasi dan Informatika, hal ini terlihat dari beberapa kali pergantian kepala badan pada Badan Litbang SDM. Rumusan masalah untuk penelitian ini yakni: Seberapa besar pengaruh komunikasi internal terhadap motivasi kerja; Seberapa besar pengaruh gaya kepemimpinan terhadap motivasi kerja; dan Seberapa besar pengaruh komunikasi internal dan gaya kepemimpinan terhadap motivasi kerja. Hasil penelitian menunjukkan bahwa komunikasi internal dan gaya kepemimpinan berpengaruh terhadap motivasi kerja. Nilai koefisien korelasi 0,727, menunjukkan hubungan kedua variabel penelitian kategori kuat. Nilai koefisien determinasi menunjukkan $52,8 \%$, ditafsirkan komunikasi internal dan gaya kepemimpinan memiliki pengaruh terhadap motivasi kerja dan 47,2\% lainnya dipengaruhi oleh faktor-faktor lain diluar komunikasi internal dan gaya kepemimpinan. Komunikasi internal berpengaruh positif, komunikasi yang diciptakan antara pimpinan dan karyawan sudah sangat baik. Gaya kepemimpinan berpengaruh terhadap motivasi kerja, gaya kepemimpinan memperlihatkan sikap terbuka. Komunikasi internal dan gaya kepemimpinan berpengaruh terhadap motivasi kerja.
\end{abstract}

Kata Kunci: komunikasi internal; gaya kepemimpinan; motivasi kerja 


\section{PENDAHULUAN}

Dalam sebuah organisasi, pemimpin memengaruhi kecepatan dan hasil kerja melalui arahan, aturan, dan manajemen. Pemimpin memiliki peran strategis, wewenang dan tanggung jawab dalam memobilisasi individu, mengintegrasikan tugas dan berkomunikasi secara efektif untuk mencapai tujuan mereka (Trihastuti, 2019). Pemimpin disebut efektif, dengan memiliki pola kerja motivasi tinggi, memiliki kemauan yang kuat, melihat semua masalah secara obyektif, berusaha untuk mencapai kesuksesan, bersemangat dan merasa tertantang oleh hal-hal baru, dan melakukan komunikasi terbuka, yaitu mendengarkan bawahan, memberikan informasi secara jelas, bekerja sama dengan semua pihak, serta bekerja keras mengatasi segala kendala yang menghambat pencapaian tujuan. Pemimpin memiliki banyak peran untuk mencapai tujuan organisasi. Peran seorang pemimpin terkait integritas dan totalitas (keutuhan menyeluruh) disebut gestalt, yang terlihat saat menjalankan tugas operasional organisasi. Keith Davis (dalam Trihastuti, 2019), dalam bukunya "Human Behavior at Work, Organizational Behavior" Secara keseluruhan, pemimpin maupun bawahan tidak terlepas dari perilaku organisasi. Peran kepemimpinan tidak terlepas dari kerangka tersebut.

Muchlas (2020) mengatakan motivasi adalah hasil interaksi antara individu dengan situasinya. Sedangkan menurut Robbins (2013) motivasi merupakan perhitungan intensitas, tujuan, dan ketekunan usaha seseorang untuk mencapai impiannya. Intensitas menggambarkan seberapa keras usahanya.

Sunyoto (2013) menjelaskan motivasi kerja merupakan suatu kondisi yang mendorong individu untuk melakukan aktivitas tertentu guna mencapai keinginannya. Berdasarkan pengertian di atas maka dapat disimpulkan bahwa motivasi kerja dapat menimbulkan semangat atau dorongan kerja oleh individu atau kelompok untuk mencapai tujuannya.

Dalam uraian diatas, penulis akan mengkaitkan dengan karyawan Aparatur Sipil Negara (ASN) Kementerian Kominfo. Menurut Undang-Undang Nomor 39 Tahun 2008, Kementerian Komunikasi dan Informatika (Kominfo) ruang lingkupnya diatur dalam Undang-Undang Dasar Negara Republik Indonesia Tahun 1945, yaitu dan komunikasi dan Informasi. Misi Kementerian Kominfo adalah menyelenggarakan urusan pemerintahan di bidang komunikasi dan informatika, serta membantu Presiden dalam penyelenggaraan pemerintahan nasional. Badan Penelitian dan Pengembangan SDM
(Balitbang SDM) merupakan salah satu direktorat penunjang Kementerian Kominfo yang memiliki dua peran penting yaitu pelaksanaan penelitian dan pengembangan SDM bidang komunikasi dan informatika.

Dari hasil observasi penulis, ternyata kondisi internal dan gaya kepemimpinan berpengaruh terhadap motivasi kerja pegawai ASN di Badan Litbang SDM, Kominfo.

Berdasarkan Latar Belakang tersebut, rumusan masalah untuk penelitian ini adalah

1. Seberapa besar pengaruh komunikasi internal terhadap motivasi kerja karyawan ASN Badan Litbang SDM, Kementerian Kominfo?

2. Seberapa besar pengaruh gaya kepemimpinan terhadap motivasi kerja karyawan ASN Badan Litbang SDM, Kementerian Kominfo?

3. Seberapa besar pengaruh komunikasi internal dan gaya kepemimpinan terhadap motivasi kerja karyawan ASN Badan Litbang SDM, Kementerian Kominfo?

Maksud dan tujuan penelitian ini adalah untuk mengetahui pengaruh komunikasi internal dan gaya kepemimpinan di badan penelitian dan pengembangan sumber daya manusia terhadap motivasi kerja pegawai ASN badan penelitian dan pengembangan sumber daya manusia Kementerian Komunikasi dan Informasi. Manfaat dan tujuan penelitian ini adalah untuk menambah wawasan dan kemampuan berfikir dari penerapan teori yang diperoleh dari mata kuliah yang diterima.

\section{Gaya Kepemimpinan}

Pemimpin memiliki ciri-ciri, kepribadian, yang unik dan khas, sehingga kepribadiannya berbeda dengan orang lain. Gaya kepemimpinan adalah cara seseorang memotivasi orang lain agar mau bekerja sama untuk mencapai tujuannya. House (dalam Robbins,2006) mengidentifikasi gaya kepemimpinan. Teori ini menganalisis pengaruh kepemimpinan terhadap motivasi prilaku bawahan, kepuasan, dan pelaksanaan kerja. Teori ini membagi empat tipe kepemimpinan sebagai berikut:

1. Kepemimpinan direktif (direktif leadership), yaitu bawahan tahu secara jelas apa yang diharapkan dari mereka dan perintah-perintah khusus apa yang diberikan oleh pemimpin. Disini tidak dikenal partisipasi bawahan, atau bersifat autokratis.

2. Kepemimpinan suportif (supportive leadership), yaitu pemimpin selalu bersedia menjelaskan, 
bertindak sebagai rekanan dan mudah didekati.

3. Kepemimpinan partisipatif (partisipatif leadership), yaitu pemimpin meminta dan menggunakan saran-saran bawahan tetapi tetap berperan dalam pengambilan dan pembuatan keputusan.

4. Kepemimpinan berorientasi prestasi (achievementoriented leadership), yaitu pemimpin mengajukan tantangan-tantangan dengan tujuan yang menarik bagi bawahan, dan merangsang bawahan untuk mencapai tujuan tersebut serta melaksanakannya dengan baik.

\section{Motivasi Kerja}

Dalam penelitian ini menggunakan teori Maslow menyatakan bahwa beberapa kebutuhan yang dapat menjadi sumber motivasi, lebih kuat daripada sumber motivasi lainnya. Motivasi kerja seorang karyawan akan berpengaruh terhadap kinerja yang diperoleh dengan kebutuhan akan adanya kelompok kerja yang kompak.

1. Kebutuhan penghargaan (esteem needs), termasuk kesediaan untuk dihormati, dihargai atas prestasi, ketrampilan dan pengetahuannya.

2. Kebutuhan aktualisasi diri (self actualization needs), adalah hierarki kebutuhan tertinggi. Realisasi diri melibatkan proses mengembangkan potensi sejati, mendemonstrasikan keterampilan, pengetahuan dan potensi.

Menurut Teori hirarki kebutuhan Abraham $\mathrm{H}$ Maslow (dalam Green, 2000):

1. Kebutuhan fisiologis seperti pangan, sandang dan papan

2. Kebutuhan rasa aman, tidak dalam fisik, tetapi juga psikologis, mental dan intelektual. Kebutuhan ini juga mencakup pengamanan, keselamatan dan kontinuitas kerja, serta jaminan.

3. Kebutuhan sosial, yaitu kebutuhan akan persahabatan, rasa memiliki dan interaksi lebih dekat dengan orang lain. Dalam organisasi, ini akan membutuhkan kelompok kerja yang koheren.

4. Kebutuhan penghargaan, prestise yang pada umumnya tercermin dalam berbagai simbol status. Meliputi keinginan untuk dihormati, dihargai atas perstasi yang dicapai, pengakuan atas kemampuan dan keahlian.

5. Kebutuhan penghargaan merupakan tercermin dalam sebuah simbol status. Termasuk keinginan dihormati, dinilai pada prestasi yang dicapai, pengakuan akan keahlian.

6. Kebutuhan aktualisasi diri, kesempatan mengembangkan potensi diri, mengubahnya menjadi keterampilan yang nyata. Ini adalah hierarki kebutuhan tertinggi.

\section{Komunikasi Internal}

Pace dan Faules (2005) menunjukkan bahwa proses komunikasi organisasi berpengaruh terhadap efektivitas organisasi ditinjau dari hubungan dan realisasi tujuan organisasi. Komunikasi internal terbagi menjadi dua dimensi, yaitu komunikasi vertikal yaitu komunikasi ke bawah dan komunikasi ke atas; dan komunikasi antar rekan kerja.

Pace dan Faules (2005) mempresentasikan informasi apa yang dikomunikasikan, yaitu menceritakan apa yang dilakukan bawahannya, pencapaian, kemajuan dan rencana ke depan. Menjelaskan masalah di tempat kerja yang belum diselesaikan oleh bawahan yang mungkin membutuhkan bantuan. Memberikan saran atau ide untuk perbaikan di unit, dan Mengungkap bagaimana bawahan berpikir dan merasa tentang pekerjaan, kolega, dan organisasi mereka.

\section{Kerangka Pemikiran}

Gaya Kepemimpinan (X1)
-Kepemimpinan Direktif
-Kepemimpinan Suportif
-Kepemimpinan Partisipatif
-Kepemimpinan Orientasi Prestasi
House dalam Robbins (Robbins, 2006)
Komunikasi Internal (X2)
-Komunikasi Kebawah
-Komunikasi keatas
Pace dan Faules (Pace, 2005)

Motivasi Kerja Karyawan (Y)

-Dorongan kebutuhan fisik

-Dorongan rasa aman

-Dorongan kebutuhan kepuasan kerja

-Kebutuhan akan penghargaan diri

-Kebutuhan akan potensi kerja

Abraham H Maslow (Christopher D. Green, 2000) 


\section{Hipotesis Penelitian}

H1: gaya Kepemimpinan dan Komunikasi Internal secara parsial berpengaruh positif terhadap kinerja karyawan

H2: gaya Kepemimpinan dan Komunikasi Internal secara simultan berpengaruh positif terhadap kinerja karyawan

\section{METODE}

Metode yang digunakan dalam penelitian ini adalah metode kuantitatif dan jenis penelitian deskriptif. Penelitian ini merupakan metode penelitian kuantitatif untuk mengetahui pengaruh komunikasi internal dan gaya kepemimpinan kepala badan penelitian dan pengembangan sumber daya manusia terhadap motivasi kerja staf ASN badan penelitian dan pengembangan sumber daya manusia Kementerian Komunikasi sesuai untuk tujuan penelitian. Metode penelitian, menggunakan penelitian instrumental untuk pengumpulan data, analisis data adalah data statistik, tujuannya untuk menguji hipotesis yang telah ditetapkan (Kriyantono, 2010).

Penelitian ini menggunakan paradigma positivis, dengan pendekatan kuantitatif. Penggunaan teori untuk melakukan penelitian dan pengujian, mengukur variabel, melakukan penelitian dengan angka, dan menganalisis data menggunakan prosedur statistik. Penelitian ini berfokus pada pengujian hipotesis.

Penelitian ini menggunakan Probability sampling dengan simple random sampling melalui kuesioner. Kuesioner dalam penelitian ini berisi daftar pertanyaan yang disebar kepada 100 responden ASN Badan Litbang SDM Kementerian Kominfo.

1. Variabel bebas (X) dalam penelitian ini adalah Gaya Komunikasi Kepemimpinan (X1) dan
Komunikasi Internal (X2)

2. Variabel terikat $(\mathrm{Y})$ dalam penelitian ini adalah Motivasi Kerja

Populasi dalam penelitian ini adalah Karyawan ASN Badan Litbang SDM Kementerian Komunikasi dan Informatika berjumlah 539 orang. Penulis meggunakan ukuran sampel menurut Taro Yamane, dari total N: 539 orang.

$\mathrm{n}=\mathrm{N} / \mathrm{N}(\mathrm{d})^{2}+1$

$=539 / 539(0,1)^{2}+1$

$=539 / 5,39+1$

$=539 / 6,39$

$=84,35$ orang ( 85 orang)

Berdasarkan ukuran sampel menurut Taro Yamane diperoleh minimum sampel adalah 85 orang. Berdasarkan jumlah minimum sampel, dalam penelitian ini penulis membatasi jumlah sampel yakni 100 orang.

\section{Operasionalisasi Variabel}

Burhan Bungin (2009) memaparkan variabel merupakan fenomena yang berbeda bentuk, kualitas, kuantitas, kualitas standar, dan sebagainya. Berdasarkan gambaran teoritis yang telah diuraikan sebelumnya, terdapat indikator untuk masing-masing variabel independen dan dependen yang dapat dirinci menjadi pertanyaan penelitian sebagai berikut

1. Seberapa besar pengaruh komunikasi internal terhadap motivasi kerja karyawan ASN Badan Litbang SDM, Kementerian Kominfo?

2. Seberapa besar pengaruh gaya kepemimpinan terhadap motivasi kerja karyawan ASN Badan Litbang SDM, Kementerian Kominfo?

3. Seberapa besar pengaruh komunikasi internal dan gaya kepemimpinan terhadap motivasi kerja karyawan ASN Badan Litbang SDM, Kementerian Kominfo?

Tabel 1. Variabel Gaya Kepemimpinan (X1)

\begin{tabular}{|c|c|c|c|}
\hline Variabel & Dimensi & $\begin{array}{l}\text { Indikator } \\
\end{array}$ & Skala \\
\hline \multirow{4}{*}{$\begin{array}{l}\text { Gaya } \\
\text { Kepmimpinan } \\
\text { (X1) }\end{array}$} & $\begin{array}{l}\text { Kepemimpinan } \\
\text { Direktif }\end{array}$ & $\begin{array}{l}\text { Pemimpin memberikan nasihat spesifik kepada kelompok } \\
\text { Pemimpin mamantapkan peraturan-peraturan pokok }\end{array}$ & Likert \\
\hline & $\begin{array}{l}\text { Kepemimpinan } \\
\text { Suportif }\end{array}$ & $\begin{array}{l}\text { Adanya hubungan yang baik antara pemimpin dengan kelompok } \\
\text { Adanya hubungan yang memperlihatkan kepekaan terhadap } \\
\text { kebutuhan anggota }\end{array}$ & Likert \\
\hline & $\begin{array}{l}\text { Kepemimpinan } \\
\text { Partisipatif }\end{array}$ & $\begin{array}{l}\text { Pemimpin mengambil keputusan berdasarkan konsultasi } \\
\text { dengan kelompok } \\
\text { Pemimpin berbagi informasi dengan kelompok }\end{array}$ & Likert \\
\hline & $\begin{array}{l}\text { Kepemimpinan } \\
\text { Orientasi Prestasi }\end{array}$ & $\begin{array}{l}\text { Pemimpin menghadapkan anggota-anggota pada tujuan yang } \\
\text { menantang } \\
\text { Pemimpin mendiring kinerja yang tinggi }\end{array}$ & Likert \\
\hline
\end{tabular}

Sumber: Wirjana dan Supardo, 2005 
IKOMIK: Jurnal Ilmu Komunikasi dan Informasi 1(1) 2021 48-54

Tabel 2. Variabel Komunikasi Internal (X2)

\begin{tabular}{|c|c|c|c|}
\hline Variabel & Dimensi & Indikator & Skala \\
\hline \multirow{10}{*}{$\begin{array}{l}\text { Komunikasi } \\
\text { Internal (X2) }\end{array}$} & \multirow{6}{*}{$\begin{array}{l}\text { Komunikasi } \\
\text { Kebawah }\end{array}$} & $\begin{array}{l}\text { Pemimpin memberikan intruksi mengenai bagaimana melakukan } \\
\text { pekerjaan }\end{array}$ & \multirow{6}{*}{ Likert } \\
\hline & & $\begin{array}{l}\text { Pemimpin memberikan informasi mengenai dasar pemikiran } \\
\text { untuk melakukan pekerjaan }\end{array}$ & \\
\hline & & Pemimpin memberikan informasi mengenai kebijakan organisasi & \\
\hline & & Pemimpin memberikan petunjuk tentang praktek organisasi & \\
\hline & & Pemimpin memberikan penilaian kinerja karyawan & \\
\hline & & $\begin{array}{l}\text { Pemimpin memberikan informasi untuk mengembangkan rasa } \\
\text { memiliki tugas }\end{array}$ & \\
\hline & \multirow{4}{*}{$\begin{array}{l}\text { Komunikasi } \\
\text { Keatas }\end{array}$} & $\begin{array}{l}\text { Karyawan memberikan laporan kepada atasan terkait tugas yang } \\
\text { diberikan }\end{array}$ & \multirow{4}{*}{ Likert } \\
\hline & & Karyawan menyampaikan keluhan kepada pimpinan & \\
\hline & & Karyawan memberitahu tentang pendapat atau usulan & \\
\hline & & Karyawan menyampaikan kritik dan saran & \\
\hline
\end{tabular}

Sumber: Pace dan Faules, 2013

Tabel 3. Variabel Motivasi Kerja (Y)

\begin{tabular}{clll}
\hline Variabel & Dimensi & \multicolumn{1}{c}{ Indikator } & Skala \\
\hline \multirow{3}{*}{ Motivasi Kerja $(\mathrm{Y})$} & & Dorongan rasa aman & \\
& \multirow{2}{*}{ Motivasi Kerja } & Dorongan kebutuhan kepuasan kerja & Kebutuhan akan penghargaan diri \\
& & Kebutuhan akan potensi kerja & Likert \\
& & \\
\hline
\end{tabular}

Sumber: Maslow, 1994

\section{Uji Validitas dan Reliabilitas}

Dalam tahapan penelitian ini dilakukan sampling, pengumpulan data, uji reabilitas dan uji validitas (Sugiyono, 2009).

\section{HASIL DAN PEMBAHASAN}

Terlampir tahapan penelitian ini dilakukan sampling, pengumpulan data, uji reabilitas dan uji validitas.Dari karakteristik responden terlihat bahwa jenis kelamin responden mayoritas adalah lakilaki yakni $63 \%$, sedangkan responden perempuan sebanyak $37 \%$. Dalam pendidikan terakhir responden, tampak didominasi oleh pendidikan sarjana $(43 \%)$ dan pasca sarjana (52\%), sedangkan pendidikan lain tampak tidak begitu signifikan dibawah $4 \%$.

Uji coba instrumen dilakukan kepada 100 responden. Instrumen diuji validitasnya dengan menggunakan rumus Pearson Product Moment dengan taraf signifikan 0.01 . Untuk instrumen gaya kepemimpinan (X1), seluruh butir kuesioner (9 butir) dinyatakan valid karena temuan penelitian menunjukkan variabel X1 memperlihatkan hasil yang semua korelasinya tinggi $\left(\mathrm{r}_{\text {hitung }}>\mathrm{r}_{\text {tabel }}\right)$. Dimana nilai tersebut tergolong sangat kuat. Untuk instrumen komunikasi internal (X2), temuan penelitian menunjukkan variabel X2 memperlihatkan hasil yang semua korelasinya tinggi $\left(\mathrm{r}_{\text {hitung }}>\mathrm{r}_{\text {tabel }}\right)$. Dimana nilai tersebut tergolong sangat kuat. Sehingga 14 butir kuesioner yang dimaksud valid. Kemudian untuk variabel motivasi kerja $(\mathrm{Y})$, temuan penelitian menunjukkan variabel Y2 memperlihatkan hasil yang semua korelasinya tinggi $\left(r_{\text {hitung }}>r_{\text {tabee }}\right)$. Dimana nilai tersebut tergolong sangat kuat. Sehingga 4 butir kuesioner yang dimaksud valid.

Uji Reabilitas Variabel X1, berdasarkan hasil nilai Cronbach Alpha 0,864>0,60, dapat disimpulkan bahwa ke 9 atau semua item pertanyaan angket untuk variabel X1 adalah reliabel atau konsisten.Uji Reabilitas Variabel X2, berdasarkan hasil nilai Cronbach Alpha $0,901>0,60$, dapat disimpulkan bahwa ke 14 atau semua item pertanyaan angket untuk variabel X2 adalah reliabel atau konsisten.Uji Reabilitas Variabel Y2, berdasarkan hasil nilai Cronbach Alpha 0,932 > 0,60, dapat disimpulkan bahwa ke 4 atau semua item pertanyaan angket untuk variabel Y1 adalah reliabel atau konsisten.

Hasil keseluruhan untuk variabel X1, X2, dan Y2 dapat dilihat semuanya benar. Pada tabel Reliabilitas Statistik kolom Cronbach's Aplha diperoleh dengan beberapa item per kuesioner, dan jumlah responden memiliki nilai korelasi diatas 0,8 . Nilai ini benar-benar sangat bagus atau tergolong sangat kuat. Oleh karena itu dapat disimpulkan bahwa kuesioner dapat dikirimkan kepada responden karena 
A.C. Nugroho, and G. Wiradharma, Pengaruh Komunikasi Internal dan Gaya Kepemimpinan ...

Tabel 3. Uji Reabilitas

\begin{tabular}{lcccccc}
\hline & \multicolumn{3}{c}{ Kolmogorov-Smirnov $^{\mathrm{a}}$} & \multicolumn{3}{c}{ Shapiro-Wilk } \\
\hline & Statistic & $\mathrm{df}$ & Sig. & Statistic & $\mathrm{df}$ & Sig. \\
\hline Jumlah X1 & .085 & 100 & .069 & .975 & 100 & .055 \\
Jumlah X2 & .076 & 100 & .160 & .986 & 100 & .355 \\
Jumlah Y2 & .159 & 100 & .000 & .942 & 100 & .000 \\
\hline
\end{tabular}

a. Lilliefors Significance Correction

Tabel 4. Uji Korelasi

\begin{tabular}{llccc}
\hline & & $\begin{array}{c}\text { (Gaya Kepemimpinan) } \\
\text { Jumlah X1 }\end{array}$ & $\begin{array}{c}\text { (Komunikasi Internal) } \\
\text { Jumlah X2 }\end{array}$ & $\begin{array}{c}\text { (Motivai Kerja) } \\
\text { Jumlah Y2 }\end{array}$ \\
\hline (Gaya & Pearson Correlation & 1 & $.774^{* *}$ & $.693^{* *}$ \\
Kepemimpinan) & Sig. (1-tailed) & & .000 & .000 \\
Jumlah X1 & $\mathrm{N}$ & 100 & 100 & 100 \\
(Komunikasi & Pearson Correlation & $.774^{* *}$ & 1 & $.675^{* *}$ \\
Internal) Jumlah & Sig. (1-tailed) & .000 & & .000 \\
X2 & $\mathrm{N}$ & 100 & 100 & 100 \\
(Motivai Kerja) & Pearson Correlation & $.693^{* *}$ & $.675^{* *}$ & 1 \\
Jumlah Y2 & Sig. (1-tailed) & .000 & .000 & 100 \\
& $\mathrm{~N}$ & 100 & 100 & 100 \\
\hline
\end{tabular}

**. Correlation is significant at the 0.01 level (1-tailed).

hasil pengukuran dapat dipercaya, berdasarkan nilai korelasi yang diperoleh.

Uji Reabilitas Variabel X1, diperoleh taraf signifikansi untuk variabel X1 berdistribusi normal. Uji Reabilitas Variabel X2, diperoleh taraf signifikansi untuk variabel X2 berdistribusi normal. Uji Reabilitas Variabel Y2, diperoleh taraf signifikansi untuk variabel Y2 berdistribusi normal.

Hasil penelitian menunjukkan untuk menjawab seberapa besar hubungan komunikasi internal (X2) terhadap motivasi kerja karyawan (Y2), nilai pada corelation table adalah 0,675 ditandai dengan ** menggambarkan koefisen korelasi signifikansi di tingkat 0,0 . Nilai 0,000 menggambarkan tingkat signifikansi, ini membuktikan tingkat signifikansi 1, pada arah positif, jadi korelasi komunikasi internal (X2) terhadap motivasi kerja karyawan (Y2) dapat dikatakan signifikansi positif hubungan searah. Komunikasi internal berpengaruh positif. Komunikasi yang diciptakan antara pimpinan dan karyawan sudah sangat baik. Untuk menjawab seberapa besar hubungan gaya kepemimpinan (X1) terhadap motivasi kerja karyawan (Y2), nilai pada corelation table adalah 0,693 ditandai dengan ** menggambarkan koefisen korelasi signifikansi di tingkat 0,0 . Nilai 0,000 menggambarkan tingkat signifikansi, ini membuktikan tingkat signifikansi 1 , pada arah positif, jadi korelasi gaya kepemimpinan (X1) terhadap motivasi kerja karyawan (Y2) dapat dikatakan signifikansi positif hubungan searah. Gaya kepemimpinan berpengaruh positif terhadap motivasi kerja. gaya kepemimpinan memperlihatkan sikap terbuka.

Hasil uji Regresi Sederhana memperlihatkan bahwa komunikasi internal (X2) dan gaya kepemimpinan (X1) berpengaruh terhadap motivasi kerja (Y2). Tabel dibawah memperlihatkan nilai $\mathrm{R}$ yang merupakan simbol dari nilai koefisien korelasi. nilai korelasi adalah 0,727 , Nilai ini dapat diinterpretasikan bahwa hubungan kedua variabel penelitian ada di kategori kuat. Melalui tabel ini juga diperoleh nilai $\mathrm{R}$ Square atau koefisien determinasi (KD) yang menunjukkan seberapa bagus model regresi yang dibentuk oleh interaksi variabel bebas dan variabel terikat. Nilai KD yang diperoleh adalah $52,8 \%$. Yang dapat ditafsirkan bahwa variabel bebas X1 dan X2 memiliki pengaruh kontribusi sebesar 52,8\% terhadap variabel Y dan 47,2\% lainnya dipengaruhi oleh faktor-faktor lain diluar variabel X1 dan X2.

Hasil penelitian menunjukkan komunikasi internal dan gaya kepemimpinan berpengaruh terhadap motivasi kerja. Nilai koefisien korelasi 0,727, menunjukkan hubungan kedua variabel penelitian kategori kuat. Nilai koefisien determinasi menunjukkan 52,8\%, ditafsirkan komunikasi internal dan gaya kepemimpinan memiliki pengaruh terhadap motivasi kerja dan 47,2\% lainnya dipengaruhi oleh faktor-faktor lain diluar komunikasi internal dan gaya 
Tabel 5. Uji Regresi Sederhana

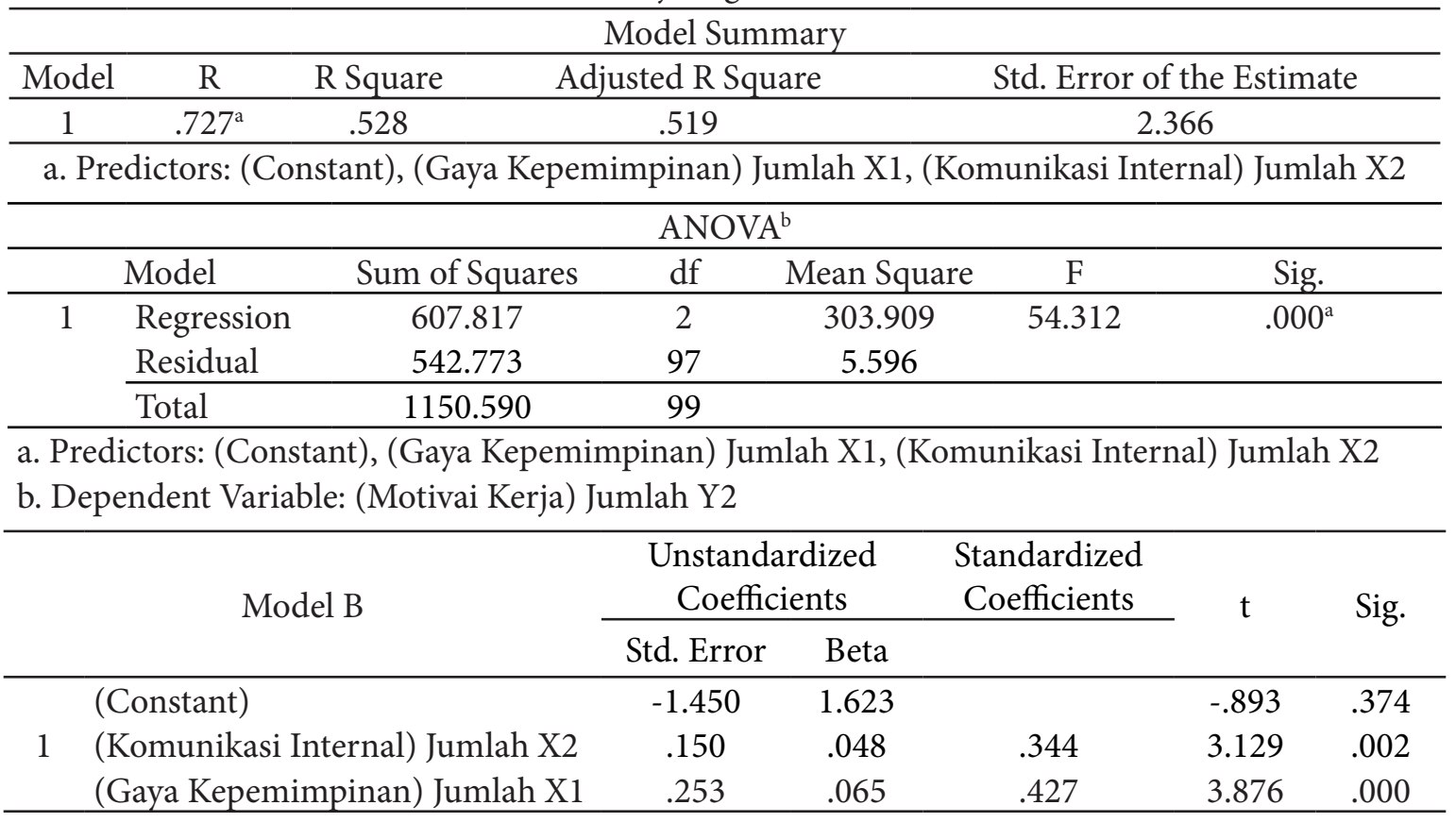

a. Dependent Variable: (Motivai Kerja) Jumlah Y2

kepemimpinan. Komunikasi internal berpengaruh positif, komunikasi yang diciptakan antara pimpinan dan karyawan sudah sangat baik. Gaya kepemimpinan berpengaruh terhadap motivasi kerja, gaya kepemimpinan memperlihatkan sikap terbuka. Komunikasi internal dan gaya kepemimpinan berpengaruh terhadap motivasi kerja.

\section{KESIMPULAN}

Berdasarkan hasil penelitisn yang dilakukan tentang pengaruh komunikasi internal (X1) dan gaya kepemimpinan (X2) terhadap motivasi kerja (Y) dapat diperoleh yakni Komunikasi internal berpengaruh positif. Komunikasi yang diciptakan antara pimpinan dan karyawan sudah sangat baik, Gaya kepemimpinan berpengaruh terhadap motivasi kerja. gaya kepemimpinan memperlihatkan sikap terbuka. Hasil penelitian memperlihatkan bahwa komunikasi internal dan gaya kepemimpinan berpengaruh terhadap motivasi kerja.

Saran yang diberikan yakni Pemimpin perlu mempertahankan kualitas pengembangan hubungan dengan pegawai, Pemimpin harus mengembangkan berbagi informasi, Pempimpin harus dapat memberikan saran dan dukungan melalui instruksi tugas, Pemimpin perlu meningkatkan dorongan kebutuhan kepuasan kerja, Pemimpin dapat meminimalisir komunikasi formal dan kaku, sehingga dapat melakukan interkasi komunikasi secara terbuka.

\section{REFERENSI}

Aselina Endang Trihastuti. (2019). Komunikasi Internal Organisasi (Cetakan Pe). DEEPUBLISH.

Bambang Septiawan. (2020). Motivasi Kerja dan Generasi Z (Teori dan Penerapannya). 2020.

Burhan Bungin. (2009). Metode Penelitian Kuantitatif, Komunikasi, Ekonomi, dan kebijakan Publik serta Ilmu-ilmu sosisal lainnya. Kencana.

Christopher D. Green. (2000). Classics in the History of Psychology: A Theory of Human Motivation. Psychological Review, 50(1), 370-396.

Danang Sunyoto. (2013). Teori, Kuisioner dan Analisis Data Sumber DayaManusia (Praktik Penelitian). Center for Academic PublishingService.

R Wayne Pace, D. F. F. (2005). Komunikasi Organisasi, StrategiMeningkatkan Kinerja Perusahaan (Dedy Mulyana (ed.)). Remaja Rosdakarya.

Rachmat Kriyantono. (2010). Teknik praktis riset komunikasi: disertai contoh praktis riset media, public relation, advertising, komunikasi organisasi, komunikasi pemasaran. Kencana.

Robbins. Stephen P. (2013). Perilaku Organisasi (Edisi 16). Salemba Humanika.

Stephen P Robbins. (2006). Prilaku Organisasi; Alih Bahasa: Handayana Pujaatmaka. Prenhallindo.

Sugiyono. (2009). Metode Penelitian Kuantitatif, Kualitatif dan R\&D. Alfabeta. 